\title{
Penyelesaian Konflik Penguasaan Tanah HGU dengan Masyarakat di Bengkulu Utara
}

\author{
Rosi Pramula Anggriawan ${ }^{1 *}$, Sutaryono ${ }^{2}$, M Nazir Salim $^{3}$ \\ ${ }^{1}$ Kantor Wilayah Badan Pertanahan Nasional Provinsi Bengkulu, Jl. Basuki Rahmat No.7, Ratu Agung, Kota Bengkulu \\ 2, Sekolah Tinggi Pertanahan Nasional, Jl. Tata Bumi No. 5 Banyuraden, Yogyakarta \\ ${ }^{3}$ Sekolah Tinggi Pertanahan Nasional, Jl. Tata Bumi No. 5 Banyuraden, Yogyakarta \\ * Korespondensi: email: rosipramula@gmail.com
}

\begin{tabular}{|c|c|}
\hline ARTICLE INFO & ABSTRACT \\
\hline $\begin{array}{l}\text { Keywords : } \\
\text { HGU, Land Conflict, Typology of } \\
\text { Conflict Resolution }\end{array}$ & $\begin{array}{l}\text { The increasing number of land conflicts, particularly over HGU (Hak Guna Usaha/Right } \\
\text { to Cultivate) land, has far-reaching implications for the community. On the one hand, } \\
\text { the community requires land, while on the other, the company seeks to defend what } \\
\text { they consider are their rights. Because this argument attracts others, it is necessary for } \\
\text { a government agency to act as a referee or facilitator to resolve the resulting conflict. } \\
\text { The purpose of this study was to identify the factors that contribute to land tenure } \\
\text { conflicts between the community and three companies that own HGU, as well as to } \\
\text { explain the role of the Ministry of ATR/BPN in resolving those conflicts. The data } \\
\text { collection method used in this study was a qualitative one presented in a descriptive } \\
\text { manner, followed by a comparative/comparative analysis of the cases. The results } \\
\text { suggested that the conflict arose because community members were inneed of land } \\
\text { reclaimed on HGU land, while HGU holders made a little positive contribution to the } \\
\text { residents surrounding the plantation. With regards to this situation, the Ministry of } \\
\text { ATR/BPN attempted to resolve it through relatively effective methods, namely acting } \\
\text { as a mediator and negotiator, delaying the HGU extension process, and eventually } \\
\text { distributing some of it to the community. The partial efforts made thus far have been } \\
\text { relatively effective and provide a sense of security for the landowners. }\end{array}$ \\
\hline
\end{tabular}

INFO ARTIKEL

\section{Kata Kunci:}

HGU, Konflik Pertanahan, Tipologi Penyelesaian Konflik

\author{
How To Cite: \\ Anggriawan, R. P., Sutaryono., \\ Salim, M.N. (2021). \\ Penyelesaian Konflik \\ Penguasaan Tanah HGU dengan \\ Masyarakat di Bengkulu Utara. \\ Marcapada: Jurnal Kebijakan \\ Pertanahan, 1(1), 29-41
}

\section{ABSTRAK}

Meningkatnya jumlah konflik pertanahan, khususnya atas tanah HGU (Hak Guna Usaha), memiliki implikasi yang luas bagi masyarakat. Di satu sisi, masyarakat membutuhkan tanah, sementara di sisi lain, perusahaan berusaha mempertahankan apa yang mereka anggap sebagai hak mereka. Karena argumen ini menarik orang lain, maka perlu ada lembaga pemerintah yang bertindak sebagai wasit atau fasilitator untuk menyelesaikan konflik yang terjadi. Tujuan dari penelitian ini adalah untuk mengidentifikasi faktor-faktor yang berkontribusi terhadap konflik penguasaan tanah antara masyarakat dengan tiga perusahaan pemilik HGU, serta menjelaskan peran Kementerian ATR/BPN dalam menyelesaikan konflik tersebut. Metode pengumpulan data yang digunakan dalam penelitian ini adalah metode kualitatif yang disajikan secara deskriptif, dilanjutkan dengan analisis komparatif/perbandingan kasus. Hasil penelitian menunjukkan bahwa konflik muncul karena masyarakat membutuhkan lahan reklamasi di atas lahan HGU, sedangkan pemegang HGU memberikan sedikit kontribusi positif bagi warga sekitar perkebunan. Berkaitan dengan situasi ini, Kementerian ATR/BPN berupaya menyelesaikannya melalui cara yang relatif efektif, yaitu bertindak sebagai mediator dan negosiator, menunda proses perpanjangan HGU, dan akhirnya membagikan sebagian kepada masyarakat. Upaya parsial yang dilakukan selama ini relatif efektif dan memberikan rasa aman bagi pemilik tanah. 


\section{A. Pendahuluan}

Negara agraris menempatkan tanah sebagai pilar utama dalam rangka penyelenggaraan hidup (Sumardjono, 2008). Sebagai pemegang kuasa tertinggi atas sumberdaya agraria, negara memiliki hubungan secara hukum dan wewenang dalam pengaturan penguasaan yang kemudian disebut sebagai hak menguasai negara (Sembiring, 2012, Sembiring, 2016). Realitas itu menempatkan sejak Orde Baru negara mengendalikan tanah dengan memberikan izin konsesi kepada perusahaanperusahaan perkebunan swasta dengan skala besar (Rachman, 1999, Salim, Yusuf, Sukayadi, 2013). Hal ini menyebabkan ketidakadilan dalam penguasaan tanah karena lahan-lahan strategis dikuasai segelintir orang dan ujungnya menciptakan banyak konflik agraria.

Pada dasarnya konflik agraria dan konflik struktural (Rachman, 2013) dipicu oleh kebijakan pemerintah dalam memberikan kemudahan dan konsesi-konsesi kepada investor dengan dalih kepentingan pembangunan dan pertumbuhan ekonomi (Sutaryono, 2002). Situasi tersebut menggeser tanah yang sebelumnya sebagai fungsi sosial menjadi fungsi komoditas. Situasi tersebut (konflik) yang semula laten berkembang dan muncul ke permukaan publik (Sembiring, 2006, Widiyanto, 2013).

Catatan Akhir Tahun Konsorsium Pembaruan Agraria (KPA), pada tahun 2018, konflik sektor perkebunan cukup tinggi, yakni 144 Konflik, sektor properti 137 (33\%), sektor pertanian 53 (13\%), pertambangan 29 (7\%), sektor kehutanan 19 (5\%), sektor infrastruktur $16(4 \%)$ dan terakhir sektor pesisir/kelautan dengan 12 (3\%). Dari 144 konflik agraria yang terjadi di sektor perkebunan, sebanyak 83 kasus 60\%-nya terjadi di perkebunan komoditas kelapa sawit dengan luasan $\pm 591.640,32$ hektar. Sebaran konflik agraria ini sebagian besar berada di sepanjang Pulau Sumatera, Pulau Sulawesi, dan Pulau Jawa bagian barat dan bagian timur (KPA, 2018, Salim \& Utami, 2019). Pada tahun 2020 konflik mengalami penurunan, namun sektor perkebunan masih menempati posisi tertinggi sebagai sektor penyumbang konflik agraria dengan 122 konflik, kehutanan 41, pembangunan infrastruktur 30, properti 20, tambang 12, fasilitas militer 11, pesisir dan pulau-pulau kecil 3, dan agribisnis 2 (KPA, 2020).

Catatan KPA pada tahun 2019 menunjukkan terdapat 93 lokasi seluas 123.064,48 ha yang menjadi Lokasi Prioritas Reforma Agraria (LPRA) dalam Hak Guna Usaha (HGU) perkebunan perusahaan swasta. Sebanyak 17 lokasi wilayah LPRA tersebut berada di Provinsi Bengkulu dan 16 lokasi tersebar di beberapa Kecamatan di Kabupaten Bengkulu Utara. Akar persoalan konflik tidak tunggal, melainkan berbagai faktor, di antaranya, penyerobotan lahan oleh perusahaan, klaim lahan adat, ketimpangan penguasaan lahan di masyarakat, dan hilangnya akses warga desa ke ladang. Dalam konteks itulah kajian ini mencoba melihat secara lebih detail bagaimana persoalan konflik agraria, khususnya HGU yang terjadi di Bengkulu (Bengkulu Utara) harus dijelaskan, utamanya melihat perbandingan antarwilayah konflik dan proses penyelesaiannya, karena selama ini banyak kritik terhadap lembaga pemerintah dalam menangani penyelesaian konflik yang tidak holistik dan komprehensif (Mulyani, 2014).

Kabupaten Bengkulu Utara terdapat beberapa kasus yang sedang dalam upaya penyelesaian konflik dan sebagian sudah berhasil diselesaikan, di antaranya: 1) PT. Bimas Raya Sawitindo dengan masyarakat di Kecamatan Air Napal; 2) PT. Sandabi Indah Lestari dengan masyarakat di Kecamatan Ketahun; 3) PT. Pamor Ganda dengan masyarakat di Kecamatan 
Pinang Raya. Beberapa kasus di atas merupakan contoh dari kasus konflik penguasaan lahan antara perusahaan pemilik modal dengan masyarakat yang ada di Kabupaten Bengkulu Utara. Di sinilah peran negara dalam pengakuan hak atas tanah kepada masyarakat merupakan salah satu hal penting bagi masyarakat untuk menggarap tanahnya secara maksimal dan aman.

Penelitian mengenai konflik penguasaan lahan antara perusahaan swasta dengan masyarakat sebagian telah diteliti di antaranya; kajian Hidayat (2004) yang menganalisis bentuk bentuk penyelesaian konflik reclaiming dan pendudukan tanah dilihat dari hukum nasional di Provinsi Bengkulu. la menjelaskan bahwa faktor penyebab konflik sangat beragam dan peran pemerintah dalam penyelesaian permasalahan tidak bisa dilihat dari satu sudut pandang saja, karena tidak menutup kemungkinan akan dapat menyebabkan konflik baru yang bahkan lebih besar. Sementara studi Manurung (2013) memandang bahwa sengketa dan konflik pertanahan yang muncul dalam masyarakat tidak selamanya dapat diselesaikan melalui peraturan perundang-undangan saja atau secara litigasi. Walaupun memang secara teoritik cara litigasi dianggap akan menjamin kepastian hukum, namun penyelesaian secara nonlitigasi menjadi bagian penting dalam penyelesaian sengketa dan konflik pertanahan agar tercipta suasana yang kondusif.

Studi terakhir diangkat oleh Ramadhani \& Salim (2017) terkait obyek HGU di Kabupaten Rejang Lebong di mana gelombang reklaiming muncul oleh warga yang merasa lahan tersebut adalah miliknya dan seharusnya pemerintah dengan mudah menyelesaikannya karena dianggap cacat administrasi dalam proses penerbitannya. Tiga studi di atas membantu menjelaskan sebagian konflik yang terjadi di Bengkulu Utara dengan berbagai tampilan data yang relatif luas, akan tetapi masih banyak hal yang belum digali secara detail terkait konflik perkebunan di Bengkulu, khususnya Bengkulu Utara, yang belum banyak penulis temukan kajian terkait. Penulis mengangkat isu tersebut karena salah satunya melihat peluang untuk menghadirkan model penyelesaian agar bisa dilihat dan dipelajari model penyelesaian konflikkonflik perkebunan di Bengkulu Utara. Penulis mencoba melihat beberapa model penyelesaian konflik dengan pendekatan Thomas dan Kilmann (Wirawan 2013) yang melihat penyelesaian konflik dari sisi kompetisi, kolaborasi, kompromi, menghindar, dan akomodasi. Pada praktiknya, berbagai model ini digunakan oleh pengambil kebijakan di Bengkulu Utara dalam kerangka mewujudkan penyelesaian konflik di level tapak, karena sesungguhnya konflik di Bengkulu Utara lebih pada konflik struktural yang telah terjadi dalam waktu yang relatif lama.

Studi ini diharapkan dapat mengisi sela-sela kosong terkait penyelesaian konflik penguasaan lahan Hak Guna Usaha dengan masyarakat terutama peran dan pola penanganan yang dilakukan oleh Kementerian Agraria dan Tata Ruang/Badan Pertanahan Nasional dengan mengkomparasikan beberapa kasus yang terjadi di Bengkulu Utara.

\section{B. Metode}

Studi ini dilakukan di Kabupaten Bengkulu Utara di mana masing-masing wilayah perusahaan pemegang Hak Guna Usaha di Kecamatan Air Napal, Kecamatan Pinang Raya, dan Kecamatan Ketahun. Penulis melakukan observasi dan pengambilan data di 3 kecamatan tersebut. metode pengumpulan datanya menggunakan metode kualitatif dengan pendekatan penyajian datanya secara deskriptif untuk menjawab persoalan mengenai faktor penyebab konflik dan bagaimana 
peran lembaga pemerintah (Kantor Pertanahan Kabupaten Bengkulu Utara) dalam penyelesaian konflik penguasaan lahan. Pengumpulan datanya dilakukan dengan melakukan observasi, wawancara, dan studi dokumen (Raco, 2010). Untuk menjawab pertanyaan mengenai tipologi penyelesaian konflik, penulis menggunakan pendekatan komparatif. Pendekatan ini bermaksud untuk membandingkan dua atau lebih kasus konflik di Bengkulu Utara sebagaimana sampel yang penulis ambil (Creswell, 2012; Sugiyono, 2013). Analisis data dalam studi ini menggunakan model Miles dan Huberman (1992), diawali dengan pengumpulan data, reduksi, penyajian, dan menarik kesimpulan.

\section{Bengkulu Utara, HGU, dan Konflik}

1. Konflik HGU PT. Bimas Raya Sawitindo dengan Masyarakat di Kec. Air Napal

a. Riwayat Penguasaan dan Akar Konflik

PT. Varietas Indah yang merupakan pemilik HGU sebelum PT. Bimas Raya Sawitindo memperoleh penguasaan hak atas lahan HGU No. 01 berdasarkan SK. Mendagri No.47/HGU/DA/1987 tanggal 21 Juli 1987 dengan wilayah administrasi Kecamatan Kerkap yang sekarang menjadi Kecamatan Air Napal. Seiring berjalannya waktu, akibat pailit dilakukanlah lelang sehingga PT. Bimas Raya Sawitindo menjadi pemenang lelang terhadap barang sitaan Negara atas penguasaan tanah HGU seluas $3000 \mathrm{Ha}$ atas nama PT. Varietas Indah seharga Rp.370.000.000. Lalu pada pada tanggal 4 Juli 1998 dilakukan proses balik nama dan ganti blanko hingga terbitlah HGU No.7 dengan SU No. 2327/1998 dengan luas $3000 \mathrm{Ha}$. Proses Balik Nama tersebut telah dikuatkan dengan Keputusan Menteri Negara Agraria/Kepala BPN Nomor: 6-VIII-1998 tentang Pemberian Ijin Pemindahan Hak Guna Usaha atas Tanah Terletak di Kabupaten Bengkulu Utara Provinsi Bengkulu Tanggal 17 Juni 1998.

Akar permasalahan konflik Hak Guna Usaha No. 01 PT. Varietas Indah sebenarnya bermula semenjak penerbitan HGU bersyarat yakni perusahaan harus mengganti rugi lahan yang akan diterbitkan oleh negara kepada masyarakat dan menurut pengakuan beberapa orang-orang lama di kalangan masyarakat bahwa HGU tersebut berdiri bukan sepenuhnya diatas tanah negara bahkan ketika pengukuran dahulu dan pemasangan patok HGU mereka tidak menyangka bahwa wilayah mereka akan dijadikan milik perusahaan, disisi lain perusahaan menganggap bahwa mereka sudah memiliki hak yang secara sah yang diberikan negara dengan syarat mengganti rugi lahan yang diberikan. Namun ketika HGU sudah terbit seluas $3000 \mathrm{Ha}$ kewajiban perusahaan belum juga dilaksanakan terhadap $\pm 1150 \mathrm{Ha}$ milik masyarakat. Seiring berjalannya waktu PT. Varietas Indah melakukan pinjaman kepada Bank Pembangunan Indonesia. Akibat pengelolaan yang kurang baik, PT. Varietas Indah mengalami pailit dan kesulitan dalam rangka penyelesaian jaminan hutang di bank. Kemudian tidak terjaganya dengan baik patok-patok batas bidang tanah serta status quo yang panjang tersebut dimanfaatkan oleh beberapa masyarakat untuk menguasai kembali dan menanam tanaman keras sekaligus menginginkankan hak atas tanah garapan yang digarap tersebut baik karena sengaja atau ketidaksengajaan. Permasalahan kemudian menjadi konflik yang kompleks dengan adanya peralihan jual beli tanah garapan oleh penjual kepada pihak lain yang kemudian dialihkan lagi kepada penggarap lain lagi. 
Semenjak penggarapan masyarakat, sejak tahun 1996-1997 sampai dengan 2018 dimana konflik ini belum dapat juga terselesaikan. Bahkan sejak peralihan lelang tahun tanggal 06 Januari 1997 yang dimenangkan oleh PT. Bimas Raya Sawitindo telah dimulai upaya baru dalam rangka penanganan permasalahan warga/masyarakat dengan pihak perusahaan untuk menempuh jalan terbaik dengan difasilitasi pihak instansi khususnya ATR/BPN.

Semenjak status pemilikan HGU No. 01 dan diganti blangko menjadi HGU 07 atas nama PT. Bimas Raya Sawitindo, penguasaan fisik garapan PT. Bimas Raya Sawitindo terkendala pada sebagian haknya digarap oleh masyarakat yang mengokupasi lahan HGU tersebut. Dan Bapak Junaidi (Kepala HRD sekaligus Humas) PT. Bimas Raya Sawitindo menyatakan bahwa mulai tahun 2008 hingga tahun 2019 masing-masing pihak terus membuat upaya penyelesaian dengan cara masyarakat yang mengembalikan tanah dan diberikan uang sebagai ganti rugi atau uang garap mereka atas tanam tumbuh namun ada juga yang tidak mau karena memang bersikeras menganggap bahwa itu tanah milik mereka.

b. Titik Temu Penyelesaian Konflik

Berdasarkan dari upaya musyawarah tanggal 09 Maret 2018 yang kemudian dilanjutkan tanggal 23 Maret 2018, memperoleh hasil bahwa pihak penggarap dan pihak perusahaan PT. Bimas Raya Sawitindo belum mendapatkan kesepakatan akan harga baik terhadap tanah yang pernah dibebaskan perusahaan seluas \pm 1100 Ha namun dikuasai kembali oleh masyarakat maupun tanah seluas \pm 1150 Ha yang belum dibebaskan oleh perusahaan dan dimohonkan ganti rugi oleh masyarakat penggarap. Bahwa terhadap HGU 07 atas nama PT. BRS telah diajukan perpanjangan haknya dimulai pada tanggal 01-02-2016 (2 tahun sebelum berakhir hak HGU 31 -12-2018) dan dijawab surat oleh Kakanwil BPN Provinsi Bengkulu tanggal 13-10-2016 perihal Perpanjangan HGU kemudian dengan meminta PT. BRS terlebih dahulu mengurus perizinan keluar dari database tanah terindikasi terlantar. Lalu PT. BRS mengurus perizinan penggunaan tanah berupa Kebun Kelapa Sawit dan telah diperoleh izin berdasarkan Surat Keputusan Bupati Bengkulu Utara Nomor 669 Tahun 2008 tentang Pemberian Izin Usaha Perkebunan Untuk Budidaya (IUP-B) PT Bimas Raya Sawitindo tanggal 29-11-2008 dan dalam pengurusan menurut PT. BRS telah sesuai dengan ketentuan yang berlaku.

Penyelesaian permasalahan tanah yang sudah dibebaskan oleh PT.BRS tapi masih dalam penguasaan masyarakat (seluas $\pm 1.100 \mathrm{Ha}$ ) dan pada akhir kesimpulannya PT. Bimas Raya Sawitindo gagal melakukan upaya mediasi ganti rugi ulang kepada pihak masyarakat penggarap dan tidak tercapai kesepakatan harga ganti rugi. Maka setelah dilakukan, HGU PT. Bimas Raya Sawitindo dapat dikeluarkan dari database Tanah Terindikasi Terlantar dan dilakukan Proses Perpanjangan HGU, dan guna penyelesaian sengketa penguasaan dan pemilikan Pihak PT. BRS telah membuat Surat Pernyataan tanggal 21 Agustus 2018 pernyataan bersedia melepaskan hak (seluas $\pm 1.100 \mathrm{Ha}$ ) yang kemudian menjadi dasar Badan Pertanahan Nasional melakukan Redistribusi Tanah atas lahan Eks. Hak Guna Usaha pada tahun anggaran 2019 dan 2020. Sehingga, dari 3000 Ha luas HGU PT. BRS sekarang hanya tersisa $760 \mathrm{Ha}$ saja yang dikuasai pihak perusahaan.

Penguasaan tanah yang dikuasai HGU sekarang hanya sekitar $\pm 25 \%$ dari apa yang diberikan oleh negara pada tahun 1988. Ini menunjukkan bahwa pada era 1980an negara 
dengan mudah memberikan lahan kepada pihak pemodal untuk membuka usaha dan kesalahan-kesalahan minor lain yang membuat hak dari masyarakat selama bertahun-tahun dirugikan sebelum akhirnya dikembalikan lagi oleh negara melalui program redistribusi tanah dengan pertimbangan aset dan aksesnya.

\section{Konflik HGU PT. Sandabi Indah Lestari dengan Masyarakat di Kec. Pinang Raya}

a. Riwayat Penguasaan dan Akar Konflik

HGU PT. Sandabi Indah Lestari merupakan alih lelang dari lahan yang sebelumnya PT. Way Sebayur dan PT. Tri Manunggal Pacific Abadi (TPA). PT. Way Sebayur memperoleh penguasaan) HGU No.33 berdasarkan SK. Mendagri No.50/HGU/DA/1987 tanggal 21 Juli 1987 dengan wilayah administrasi Desa Bukit Harapan dengan luas 6.328 Ha Sedangkan PT. Tri Manunggal Pacific Abadi memperoleh penguasaan hak atas tanah yaitu HGU No. 11 dengan luas $3.000 \mathrm{Ha}$ berdasarkan SK. Mendagri No.38/HGU/DA/1988 tanggal 09 Mei 1988.

Konflik yang terjadi antara PT. SIL dengan masyarakat Desa Simpang Batu dan Lembah Duri bermula dari, pihak manajemen PT. SIL yang membeli lahan bekas perusahaan PT. Way Sebayur dan PT. TPA, yang ternyata sudah banyak dikuasai masyarakat. Puncaknya 27 Februari 2013, terjadi pembakaran aset-aset perusahaan oleh masyarakat, sehingga menyebabkan konflik yang rumit. Penguasaan lahan milik masing-masing perusahaan pada awalnya berjalan dengan sebagaimana mestinya, namun dikarenakan terjadinya konflik internal dan juga pailit menjadikan keadaan lahan di lapangan menjadi terbengkalai. Status quo yang panjang atas lahan PT. Way Sebayur dan PT. Tri Manunggal Pacific Abadi menyebabkan masyarakat sekitar dan banyak masyarakat dari daerah luar kabupaten berbondong-bondong menggarap lahan yang dianggap terbengkalai dan terlantar tersebut.

Di era awal tahun 2000an tersebut setelah mulai banyak digarap oleh masyarakat, maka sudah mulai timbul penggarapan dan juga proses jual beli atas lahan bekas milik HGU yang terbengkalai tadi. Bahkan pada saat itu harga tanah untuk satu bidang dengan luasan $2 \mathrm{Ha}$ hanya diperjual belikan berkisar 2- 4 juta saja. Seiring berjalannya waktu masyarakat memperkuat kelompok agar apa yang sudah mereka kuasai dapat mereka miliki seutuhnya. Seiring perkembangannya, bekas HGU perkebunan coklat tersebut akhirnya diubah menjadi perkebunan sawit oleh masyarakat. Semenjak penggarapan masyarakat, sejak tahun 2000an sampai dengan sekarang konflik ini belum dapat juga terselesaikan. Permasalahan kemudian menjadi konflik yang lain lagi dengan adanya peralihan jual beli tanah garapan oleh penjual yang sekarang menguasai bidang tanah sampai dengan $50 \mathrm{Ha}$.

Pada tahun 2020, Pemda Provinsi Bengkulu kembali melakukan mediasi terhadap konflik Agraria antara PT. Sandabi Indah Lestari (SIL) Eks HGU PT Way Sebayur dan HGU PT Tri Manunggal Pasifik Abadi dengan warga Kabupaten Bengkulu Utara. Bahkan Pemprov Bengkulu sudah 3 kali melakukan mediasi, namun belum ada keputusan yang kuat untuk menyelesaikan konflik ini. Untuk HGU nomor 33 seluas 4.971 hektar masyarakat menuntut untuk di enclavekan seluas 1.308 hektar, sedangkan HGU nomor 11 seluas 3000 hektar dengan permintaan masyarakat untuk meng-enclave seluas 715,5 hektar. Meskipun sudah cukup banyak bidang tanah dilakukan redistribusi tanah hasil enclave perusahaan, namun hingga kini masih ada tanah garapan masyarakat yang secara administratif merupakan pemilikan perusahaan. 


\section{b. Titik Temu Penyelesaian Konflik}

Pada Tanggal 17 Januari 2012 dibentuklah Tim Inventarisasi dan Pengecekan Penggarap dalam lokasi PT. SIL yang terdiri Pemkab Bengkulu Utara, dan instansi terkait, wakil masyarakat penggarap yang dikuasakan kepada Kantor Bantuan Hukum Bengkulu (KBHB) Arga Makmur, sesuai kesepakatan tim akan turun kelapangan setelah ada data awal dari wakil masyarakat penggarap (KBHB). Lalu dibentuklah Tim Inventarisasi Penggarap Lahan pada lokasi PT. Sandabi Indah Lestari di Kecamatan Ketahun Kabupaten Bengkulu Utara dengan SK. Bupati Bengkulu Utara Nomor: 54 Tahun 2012 tanggal 20 Februari 2012. Kemudian dilaksanakan Gelar Perkara Eksternal BPN RI tanggal 21-02-2012 yang inti penyelesaian bahwa:

1. PT. SIL bersedia menyelesaikan penggarapan yang ada kepada para penggarap dengan memberikan kompensasi yang bentuk dan jumlahnya disepakati oleh kedua belah pihak

2. PT. SIL bersedia melakukan enclave terhadap masyarakat yang secara sungguhsungguh adalah petani yang memerlukan lahan untuk kelangsungan hidupnya, kemudian administrasi pelaksanaannya akan ditindaklanjuti para pihak dengan pengawasan pemerintah daerah.

3. Bagi masyarakat yang tidak bersedia melaksanakan alternatif pertama dan kedua dapat menyelesaikan melalui litigasi.

Kemudian terhadap HGU 33 telah diajukan perpanjangan haknya dan telah melengkapi persyaratan dan proses telah berjalan Panitia B dan perkembangan berkas sudah direkomendasi ke BPN Pusat. HGU 33 dan HGU 11 direncanakan pemisahan/enclave sebagian haknya guna memenuhi penyelesaian petani penggarap desa lembah duri dan desa simpang batu, rencana enclave seluas $1200 \mathrm{Ha}$ untuk petani 613 Kepala Keluarga. HGU No. 33 telah dipisahkan/enclave sebagian haknya guna memenuhi penyelesaian petani penggarap Desa Lembah Duri dan Desa Simpang Batu, telah dilakukan enclave ke Desa Air Sebayur 568,185 Ha, dan di Urai 263,41 Ha, kemudian juga telah dilakukan redistribusi tanah kepada penggarap melalui program redistribusi tanah 2015 Kantor Pertanahan Kabupaten Bengkulu Utara sebanyak 100 persil atas nama Rohidi, cs dengan total luasan 162,2858 Ha. Akhirnya, meskipun sudah banyak lahan yang di enclave-kan untuk diserahkan ke masyarakat tetap saja masih banyak lahan masyarakat yang masih di wilayah HGU yang mana pada kenyataan lapangannya masyarakat yang menguasai dan belum bersedia dilepaskan oleh pihak perusahaan. Kantor Pertanahan dalam penyelesaiannya cenderung kompromi dan berada di tengah, dengan strategi memberi dan mengambil (take and give). Sementara kedua belah pihak yang berkonflik mencari alternatif yang memuaskan sebagian keinginan masing-masing (Wirawan, 2013).

\section{Konflik HGU PT. Pamor Ganda dengan Masyarakat di Kec. Ketahun}

a. Riwayat Penguasaan dan Akar Konflik

PT Pamor Ganda memperoleh wewenang penguasaan atas HGU Nomor 16, tanggal 27 Juli 1989, Surat Ukur Sementara tanggal 15 Desember 1988 Nomor 11/PT/1988 seluas 2.600 ha berdasarkan Surat Keputusan Kepala Badan Pertanahan Nasional tanggal 27 Juni 1989 Nomor 35/HGU/BPN/1989. Pada tanggal 31 Desember 2019 HGU tersebut habis jangka 
waktunya, menyangkut masalah perpanjangan HGU Nomor 16 PT. Pamor Ganda Ketahun tadi, masyarakat Desa Lubuk Mindai dll menolak untuk perpanjangan HGU PT. Pamor Ganda dan menuntut kepada PT. Pamor Ganda tentang perkebunan masyarakat yang berada di aliran sungai di Desa Lubuk Mindai yang tidak bisa membuat surat tanah atau Sertipikat Adapun lahan masyarakat yang tidak bisa dibuat Sertipikat diakibatkan oleh PT. Pamor Ganda Ketahun sebanyak + 50 ha (lima puluh hektar) juga meminta membebaskan lahan yang berada di wilayah PT. Pamor Ganda Ketahun kepada masyarakat Desa Lubuk Mindai untuk pemukiman dan pecahan Kartu Keluarga (KK) seluas 50×50 meter per KK dengan jumlah Kartu Keluarga + 267 (dua ratus enam puluh tujuh).

Karena belum adanya penyelesaian dari PT. pamor Ganda dan Pemerintah Daerah, maka seluruh masyarakat Desa Lubuk Mindai memohon kepada pihak yang terkait untuk dapat menyelesaikan permasalahan HGU PT. Pamor Ganda Ketahun dengan seadil-adilnya dan secepat-cepatnya. Kemudian warga Desa Lubuk Mindai dan desa penyangga lainnya pun melakukan demo dengan melakukan tuntutan yakni permintaan antara lain:

1. PT. Pamor Ganda diminta agar menjelaskan dasar pemberian kompensasi dan lahan kepada Desa penyangga tanah HGU 1 (satu).

2. Perusahaan PT. Pamor Ganda harus menghargai semua proses hukum yang sedang ditempuh oleh Pemerintah Desa penyangga terhadap masalah apapun yang patut diduga bersinggungan atau berhubungan dengan HGU PT Pamor Ganda baik langsung maupun tidak langsung.

3. Pelepasan tanah warga bersertifikat yang ada di wilayah HGU Pamor Ganda serta memberikan kompensasi kerugian selama 30 tahun.

4. Pelepasan dan pembebasan tanah $\mathbf{1 0 0}$ meter kanan kiri bahu jalan baik jalan lintas Sumatera dan jalan Tambang

5. Memberikan peluang pekerjaan kepada masyarakat desa penyangga sesuai porsinya secara adil merata (Pasal 27 UUD 45 ayat 2).

6. PT. Pamor Ganda harus menunjukkan Peta HGU lama, dan pengukuran ulang HGU PT. Pamor Ganda bersama perwakilan atau masyarakat desa penyangga.

7. Tidak ada diskriminasi karyawan dari desa penyangga pasca aksi damai .

8. Pihak perusahaan memberikan kenang-kenangan kompensasi kepada masyarakat/pemerintah desa seperti yang diberikan desa penyangga di HGU PT. Pamor Ganda, melaksanakan kewajiban sesuai peraturan Menteri Agraria dan Tata Ruang/KBPN No. 7 tahun 2007 Pasal 40 huruf K dan Pasal 41 No. 1.

9. Kewajiban memfasilitasi pembangunan kebun masyarakat paling sedikit $20 \%$ dari luasan lahan yang dimohon.

10. Relokasi sempadan sungai terikat habitat dan ekosistem sesuai Peraturan Pemerintah Republik Indonesia No 38 tahun 2011 pasal 5 ayat (2) UUD RI 1945 UU No 7 tahun 2004 tentang sumber daya air (Lembaran Negara Republik Indonesia tahun 2004 No 32 Lebaran Negara RI No 4377)

Mengenai perpanjangan izin hak guna usaha, menurut Oloan Sitorus (2016) menyatakan jika jangka waktu hak atas tanah yang terbatas itu berakhir, maka status tanahnya menjadi 
tanah negara. Namun, praktik administrasi pertanahan selama ini menunjukkan bahwa kepada bekas pemegang hak guna usaha tetap memperoleh hak prioritas atau hak keperdataan. Tidak jarang dari sisi inilah pula cukup banyak menuai konflik dimana kesenjangan penguasaan lahan itu bakal terus berlanjut.

b. Titik Temu Penyelesaian Konflik

Pada Tanggal 31 Oktober 2019 Polres Bengkulu Utara mengundang Kepala Kantor Pertanahan Kabupaten Bengkulu Utara untuk melakukan mediasi penyelesaian konflik antara PT. Pamor Ganda dengan warga Desa Lubuk Mindai yang dilaksanakan pada hari Selasa, tanggal 5 November 2019 bertempat di Polsek Ketahun. Kemudian pada Tanggal 5 November 2019, Pihak Kantor Pertanahan Kabupaten Bengkulu Utara memenuhi undangan Polres Bengkulu Utara untuk melakukan mediasi penyelesaian konflik antara PT. Pamor Ganda dengan warga Desa Lubuk Mindai di Polsek Ketahun. Lalu dilanjutkan tanggal 20 November 2019, PT. Pamor Ganda mengirim surat ke Kantor Pertanahan Kabupaten Bengkulu Utara dengan Nomor Surat 64/KDR/PG/BKL/XI/2019 tentang Permohonan Pendaftaran SK Perpanjangan Jangka Waktu HGU SK Menteri ATR/Kepala BPN Nomor 108/HGU/KEM-ATR/BPN/X/2019.

Pada tanggal 25 November 2019, Kantor Pertanahan Kabupaten Bengkulu Utara membalas surat PT. Pamor Ganda dengan Nomor Surat 283/300-17.13/XI/2019 tentang Pendaftaran SK Perpanjangan Jangka Waktu HGU SK Menteri ATR/Kepala BPN Nomor 108/HGU/KEM-ATR/BPN/X/2109. Lalu perwakilan masyarakat Desa Lubuk Mindai mengirim surat ke Kantor Pertanahan Kabupaten Bengkulu Utara dengan Nomor Surat 311/SK/LBM/XI/2019 tentang Permohonan Penyelesaian Sengketa Lahan Masyarakat.

Pada tanggal 5 Desember 2019, PT. Pamor Ganda melengkapi berkas permohonan pendaftaran SK Perpanjangan Jangka Waktu HGU SK Menteri ATR/Kepala BPN Nomor 108/HGU/KEM-ATR/BPN/X/2019 untuk kemudian didaftarkan ke Sistem Komputerisasi Kegiatan Pertanahan (KKP). Kemudian perwakilan masyarakat Desa Lubuk Mindai mengirim surat ke Kantor Pertanahan Kabupaten Bengkulu Utara dengan Nomor Surat 007/SK/LBM/I/2020 tentang Penolakan Perpanjangan HGU PT. Pamor Ganda Ketahun. Pihak Polres Bengkulu Utara melakukan koordinasi dengan Kantor Pertanahan Kabupaten Bengkulu Utara terkait perkembangan permohonan perpanjangan jangka waktu HGU PT. Pamor Ganda.

Pada tanggal 21 Januari 2020, perwakilan masyarakat Desa Lubuk Mindai mengirim surat ke Kantor Pertanahan Kabupaten Bengkulu Utara tentang rencana aksi ke areal HGU PT. Pamor Ganda. Kemudian Kepala Kantor Pertanahan Kabupaten Bengkulu Utara mengirim surat kepada Kepala Kantor Wilayah BPN Provinsi Bengkulu untuk mohon petunjuk dengan Nomor Surat 21/300-17.13/I/2020. Lalu tanggal 29 Januari 2020, Kepala Kantor Pertanahan Kabupaten Bengkulu Utara mengirim surat kepada Kepala Kejaksaan Negeri Bengkulu Utara tentang Perpanjangan HGU atas nama PT. Pamor Ganda dengan Nomor Surat 35/600-17.13/1/2020. Pada dasarnya masyarakat menginginkan hal-hal sebagaimana poin poin yang menjadi akar masalah pada poin yang disebutkan di bagian sub bab sebelumnya, peran Kementerian Agraria dan Tata Ruang adalah dengan menjadi mediator dan fasilitator juga menggunakan gaya manajemen konflik avoiding yakni menunda pokok masalah hingga waktu yang tepat dan menarik diri dari konflik yang mengancam dan merugikan. Sehingga proses perpanjangan 
ditunda hingga semua masalah selesai dan dapat diberlakukan proses perpanjangan. Karena proses perpanjangan HGU harus memenuhi kewajiban berikut yaitu:

1. Membuat daftar Peserta Sistem Pola Plasma untuk disahkan oleh Bupati/Walikota/Pejabat yang ditunjuk dan Perjanjian Kerja Sama untuk diketahui oleh Bupati/Walikota/Pejabat yang berwenang;

2. Fasilitasi pembangunan kebun masyarakat seluas 455,22 ha;

3. Sertipikasi hak atas tanah atas nama masyarakat Desa Talang Baru, Desa Lubuk Mindai, Desa Tanjung Dalam dan Desa Kualalangi, Kecamatan Ketahun.

Tiga buah poin di atas dilakukan dalam waktu paling lama 3 (tiga) tahun terhitung sejak tanggal didaftarkan Keputusan Perpanjangan Jangka Waktu Hak Guna Usaha. Hingga akhirnya pada bulan April 2019, peneliti mewawancarai salah satu tokoh masyarakat di Desa Penyangga bahwa pihak perusahaan siap menyanggupi permintaan dari masyarakat yang antara lain memberikan kebun yang dikuasai masyarakat Desa Lubuk Mindai dan membuat perjanjian bagi hasil 70:30 terhadap hasil kebun, kemudian perusahaan juga bersedia memberikan kebun yang sudah menghasilkan sebagai sumbangsih ke pihak desa seluas $10 \mathrm{Ha}$ untuk menjadi aset bagi desa dalam membantu masyarakat. Hingga akhirnya riak-riak konflik pun meredam, dan proses perpanjangan HGU berjalan. Dengan menunda proses perpanjangan HGU sampai memenuhi sebagian yang diinginkan oleh masyarakat mampu meredam konflik yang terjadi.

\section{Penyelesaian Konflik HGU}

Berdasarkan data penelitian maka dapat kita simpulkan secara ringkas mengenai penyelesaian konflik HGU di kabupaten Bengkulu Utara pada tabel di bawah ini:

Tabel 1. Penyelesaian Konflik HGU di Kabupaten Bengkulu Utara

\begin{tabular}{|c|c|c|c|}
\hline & PT. BRS & PT. SIL & PT. Pamor Ganda \\
\hline Subjek & $\begin{array}{l}\text { Masyarakat } 10 \text { Desa di Kecamatan } \\
\text { Air Napal vs Perusahaan }\end{array}$ & $\begin{array}{l}\text { Masyarakat Desa Lembah } \\
\text { Duri dan Desa Simpang Batu } \\
\text { vs Perusahaan }\end{array}$ & $\begin{array}{l}\text { Masyarakat Desa Lubuk Mindai } \\
\text { dan desa penyangga vs } \\
\text { Perusahaan }\end{array}$ \\
\hline Objek & Tanah HGU No. 7 & $\begin{array}{l}\text { Tanah HGU No.33 dan HGU } \\
\text { No.11 }\end{array}$ & Tanah HGU No. 1 \\
\hline \multirow[t]{2}{*}{$\begin{array}{l}\text { Faktor Penyebab } \\
\text { Konflik }\end{array}$} & $\begin{array}{l}\text { Terbitnya HGU bersyarat } \\
\text { Kegagalan mekanisme Ganti Rugi } \\
\text { Tanah terbengkalai/ Terlantar } \\
\text { Perusahaan Pailit }\end{array}$ & $\begin{array}{l}\text { HGU terlantar dan ada pula } \\
\text { yang belum digarap } \\
\text { Perusahaan pailit hingga } \\
\text { status quo panjang }\end{array}$ & $\begin{array}{l}\text { Kurang berbagi ke desa sekitar } \\
\text { Kesalahpahaman masyarakat } \\
\text { bahwa perpanjangan HGU, } \\
\text { maka perusahaan wajib }\end{array}$ \\
\hline & $\begin{array}{l}\text { Masyarakat Menggarap tanah } \\
\text { terlantar } \\
\text { Tanah yang sudah di ganti rugi ada } \\
\text { yang dikuasai kembali } \\
\text { Peralihan tanah garapan }\end{array}$ & $\begin{array}{l}\text { Masyarakat butuh tanah } \\
\text { untuk tinggal dan usaha } \\
\text { pertanian }\end{array}$ & $\begin{array}{l}\text { melepaskan } 20 \% \text { dari wilayah } \\
\text { HGU } \\
\text { Masyarakat menganggap bahwa } \\
\text { HGU menggarap diluar batas } \\
\text { patok }\end{array}$ \\
\hline Upaya Tuntutan & $\begin{array}{l}\text { Aksi demo, } \\
\text { Penutupan jalan perusahaan }\end{array}$ & $\begin{array}{l}\text { Aksi demo, } \\
\text { Pembakaran aset }\end{array}$ & Aksi demo, dan protes \\
\hline $\begin{array}{l}\text { Permintaan } \\
\text { Masyarakat }\end{array}$ & $\begin{array}{l}\text { Enclave wilayah desa yang masuk } \\
\text { HGU } \\
\text { Ganti rugi tanah masyarakat }\end{array}$ & $\begin{array}{l}\text { Enclave wilayah kebun warga } \\
\text { HGU } \\
\text { Ganti rugi atas lahan yang } \\
\text { sudah di tanam oleh } \\
\text { masyarakat (tanaman di } \\
\text { atasnya) }\end{array}$ & $\begin{array}{l}\text { Perusahaan meng enclave } \\
\text { kebun warga yang masuk area } \\
\text { HGU } \\
\text { Perusahaan memberi sumbangsi } \\
\text { kepada desa penyangga, CSR dll }\end{array}$ \\
\hline Jenis Penanganan & $\begin{array}{l}\text { Non Litigasi berupa mediasi serta } \\
\text { pembukaan akses kepada } \\
\text { masyarakat (Redistribusi Tanah) }\end{array}$ & $\begin{array}{l}\text { Litigasi pada kasus } \\
\text { kepemilikan perorangan skala } \\
\text { besar dan Nonlitigasi berupa } \\
\text { mediasi serta pembukaan }\end{array}$ & Nonlitigasi berupa mediasi \\
\hline
\end{tabular}




\begin{tabular}{|c|c|c|c|}
\hline & & $\begin{array}{l}\text { akses kepada masyarakat } \\
\text { (Redistribusi Tanah) }\end{array}$ & \\
\hline $\begin{array}{l}\text { Jenis Pendekatan } \\
\text { Penyelesaian }\end{array}$ & Pendekatan Hak dan Akses & Pendekatan Hak & $\begin{array}{l}\text { Pendekatan Hak dan } \\
\text { Ekososiologi }\end{array}$ \\
\hline Keterlibatan BPN & Sebagai mediator & $\begin{array}{l}\text { Sebagai mediator dan sebagai } \\
\text { pihak tergugat pada kasus } \\
\text { pemilikan perorangan skala } \\
\text { besar }\end{array}$ & Sebagai mediator \\
\hline $\begin{array}{l}\text { Mekanisme } \\
\text { Penyelesaian }\end{array}$ & $\begin{array}{l}\text { Selesai dengan mekanisme RA } \\
\text { berupa Redistribusi Tanah kepada } \\
\text { masyarakat }\end{array}$ & $\begin{array}{l}\text { Sebagian selesai, sebagian lagi } \\
\text { masih dalam proses upaya } \\
\text { warga untuk meminta } \\
\text { perusahaan meng enclave kan } \\
\text { lagi HGU }\end{array}$ & $\begin{array}{l}\text { Proses Perpanjangan } \\
\text { dilaksanakan, dan tuntutan } \\
\text { masyarakat diberikan oleh pihak } \\
\text { perusahaan yaitu tanah di } \\
\text { wilayah pinggiran sungai dengan } \\
\text { sistem penjualan hasil 70:30 } \\
\text { untuk masyarakat serta } \\
\text { pemberian kebun untuk aset } \\
\text { desa }\end{array}$ \\
\hline $\begin{array}{l}\text { Strategi } \\
\text { Penyelesaian oleh } \\
\text { BPN }\end{array}$ & $\begin{array}{l}\text { Menunda atau memadamkan } \\
\text { konflik yang ada hingga waktu } \\
\text { yang tepat ( Perpanjangan HGU) } \\
\text { (Menghindar/Avoiding) }\end{array}$ & $\begin{array}{l}\text { Menjadi wadah atau } \\
\text { jembatan kedua belah pihak } \\
\text { untuk mencari solusi yang } \\
\text { dapat diterima kedua belah } \\
\text { pihak (Manajemen } \\
\text { Kompromi) }\end{array}$ & $\begin{array}{l}\text { Memberikan pemahaman atas } \\
\text { konflik yang terjadi, serta } \\
\text { menunda proses perpanjangan } \\
\text { hingga apa yang diinginkan } \\
\text { masyarakat dan perusahaan } \\
\text { terselesaikan (Manajemen } \\
\text { Akomodasi dan Kolaborasi) }\end{array}$ \\
\hline
\end{tabular}

Sumber: Hasil analisis data lapangan, 2020.

Tabel analisis di atas bisa ditarik kesimpulan, bahwa meskipun faktor penyebab konflik yang bermacam-macam dapat diselesaikan apabila masing-masing pihak dapat duduk bersama untuk mencari jalan tengah yang terbaik yang setidaknya tidak merugikan banyak pihak. Sebaiknya penyelesaian dimulai dari menghilangkan akar konflik terlebih dahulu baru kemudian mencari solusi. Pemahaman tentang akar konflik dapat membantu model-model atau solusi yang bisa ditawarkan, tentu saja harus dengan manajemen konflik yang sesuai dengan karakteristik masyarakat, jumlah subjek yang berkonflik dan tuntutan dari masingmasing pihak. Dengan cara demikian, penanganan dan pendekatan yang digunakan mampu menyelesaikan konflik yang telah berlarut-larut. Konflik-konflik agraria yang berhubungan dengan perluasan perkebunan sawit di Indonesia harus dilihat lebih luas karena konflik agraria yang berkepanjangan dapat menciptakan krisis lainnya (Rachman, 2013).

\section{E. Kesimpulan}

Pola penanganan konflik agraria dapat dilakukan dengan cara jalur formal yaitu melalui pengadilan, penertiban administrasi dan Regulasi serta jalur non formal yaitu mediasi, kompensasi, program-program pembukaan akses, dan Manajemen Konflik. Berdasarkan uraian di atas dapat disimpulkan beberapa hal mengenai faktor penyebab konflik HGU dengan masyarakat di Kabupaten Bengkulu Utara disebabkan oleh Interaksi berbagai pihak atas kepemilikan lahan antara yang dianggap "ditelantarkan" dan "belum digarap". Di satu sisi masyarakat banyak yang membutuhkan tanah, namun di sisi lain ada pihak-pihak yang menguasai banyak lahan.

Penulis mendapati, upaya penyelesaian konflik yang dilakukan adalah menunda atau memadamkan konflik yang ada hingga waktu yang tepat (Perpanjangan HGU) dengan kata lain menggunakan gaya manajemen menghindar/avoiding. Atau meredakan konflik dengan cara menjadi wadah atau jembatan kedua belah pihak untuk mencari solusi yang dapat diterima 
kedua belah pihak (kompromi). Namun juga dilakukan dengan model penyelesaian dengan cara memberikan pemahaman atas konflik yang terjadi kepada pihak-pihak yang berkonflik. Cara lain yang juga efektif dalam praktiknya adalah menunda proses perpanjangan HGU hingga apa yang diinginkan masyarakat dan perusahaan terselesaikan dan disepakati kedua pihak tanpa harus terus menerus berkonflik dan berebut lahan (akomodasi dan kolaborasi). Model-model di atas telah dilakukan oleh Bengkulu Utara dan hasilnya, dua dari 3 sampel konflik di atas mampu diselesaikan dengan mendistribusikan lahan bekas HGU kepada masyarakat.

\section{Daftar Pustaka}

Antoro, K. S. (2013). Anatomi konsep penyelesaian konflik agraria: studi perbandingan antara ranah kebijakan dan ranah perjuangan agraria. BHUMI: Jurnal Agraria dan Pertanahan, (37), 28-48.

Creswell, J. W. (2012). Research Design: Pendekatan Kuantitatif, Kualitatif,dan Mixed (Edisi Ketiga). Pustaka Pelajar.

Hidayat, M.F. (2004). Bentuk-bentuk Penyelesaian Konflik Reclaiming Pendudukan Tanah Dilihat Dari Hukum Tanah Nasional (Tesis) Fakultas Hukum Universitas Diponegoro. Semarang

Konsorsium Pembaruan Agraria. (2018). "Masa Depan Reforma Agraria Melampaui Tahun Politik", Publikasi Catatan Akhir Tahun Konsorsium Pembaruan Agraria, Jakarta.

Konsorsium Pembaruan Agraria. (2020). "Catatan Akhir Tahun 2020 Konsorsium Pembaruan Agraria, Perampasan Tanah Berskala Besar, Edisi Peluncuran I: Laporan Konflik Agraria, di Masa Pandemi dan Krisis Ekonomi. Jakarta.

Manurung, A.I. (2013). Konflik Pertanahan Antara PT. Sumbersari Petung dengan Masyarakat Penggarap di Kecamatan Ngancar Kabupaten Kediri Provinsi Jawa Timur (Skripsi). Sekolah Tinggi Pertanahan Nasional. Yogyakarta.

Miles, M.B. \& Huberman, M. (1992). Analisis data kualitatif. Jakarta: Universitas Indonesia.

Mulyani, L. (2014). Kritik atas penanganan konflik agraria di Indonesia. BHUMI: Jurnal Agraria dan Pertanahan, (39), 314-355. DOI: https://doi.org/10.31292/jb.v1i39.176; http://jurnalbhumi.stpn.ac.id/JB/article/view/176

Raco, J.R. (2010). Metode penelitian kualitatif: Jenis, karakter dan keunggulannya. Jakarta: Grasindo,.

Rachman, N.F. (1999). Petani dan penguasa: dinamika perjalanan politik agraria Indonesia. Yogyakarta: Pustaka Pelajar Offset.

Rachman, N. F. (2013). Rantai penjelas konflik-konflik agraria yang kronis, sistemik, dan meluas di Indonesia. BHUMI: Jurnal Agraria dan Pertanahan, (37), 1-14.

Ramadhani, R.D. \& Salim, M.N. (2017). Akuisisi tanah-tanah rakyat: Problem HGU PT. BMS di Rejang Lebong dan jalan penyelesaiannya. BHUMI: Jurnal Agraria dan Pertanahan, 3(1), 17-34.

Salim, M. N., Sukayadi, S., \& Yusuf, M. (2013). Politik dan Kebijakan Konsesi Perkebunan Sawit di Riau. dalam Luthfi, A. N. (2013). Membaca ulang politik dan kebijakan agraria, (Hasil Penelitian Sistematis STPN 2013), Yogyakarta: PPPM-STPN Press.

Salim, M. N., \& Utami, W. (2019). Reforma Agraria, Menyelesaikan Mandat Konstitusi: Kebijakan Reforma Agraria dan Perdebatan Tanah Objek Reforma Agraria. Yogyakarta: STPN Press. 
Sembiring, J. (2006). Konflik tanah perkebunan di Indonesia'. Jurnal Hukum, 13 (2), 279-292.

Sembiring, J. (2012). Tanah Negara. Yogyakarta: STPN Press.

Sembiring, J. (2016). Hak Menguasai Negara Atas Sumber Daya Agraria. BHUMI: Jurnal Agraria dan Pertanahan, 2(2), 119-132.

Setiyani, W. (2016). Tipologi dan Tata Kelola Resolusi Konflik Ditinjau dari Perspektif Teori Sosial Konflik. TEOSOFI: Jurnal Tasawuf Dan Pemikiran Islam, 6(2), 275-299.

Sitorus, O. (2016). Penataan Hubungan Hukum Dalam Penguasaan, Pemilikan, Penggunaan, Dan Pemanfaatan Sumber Daya Agraria (Studi Awal Terhadap Konsep Hak Atas Tanah Dan Ijin Usaha Pertambangan). BHUMI: Jurnal Agraria dan Pertanahan, 2(1), 1-11.

Sugiyono. (2013). Metode penelitian pendidikan, pendekatan kuantitatif kualitatif dan R\&D. Bandung: Alfabeta.

Sumardjono, M.S.W. (2008). Tanah Dalam Perspektif Hak Ekonomi Sosial dan Budaya. Jakarta: Kompas.

Sumardjono, M.S.W., Nurhasan, I. \& Isharyanto, (2008). Mediasi sengketa (potensi penerapan alternatif penyelesaian sengketa (ADR) di bidang pertanahan). Jakarta: Kompas.

Sutaryono. (2002) Konflik Pertanahan: Sebuah Kaca Benggala. Majalah Ilmiah Widya Bhumi, 7(3), 16.

Sutaryono, (2013). Strategi Mereduksi Konflik melalui Perluasan Lapangan Kerja dalam Bingkai Reforma Agraria. Jurnal Pertanahan, 3 1), 43-53.

Widiyanto, W. (2013). Potret Konflik Agraria di Indonesia. BHUMI: Jurnal Agraria dan Pertanahan, (37), 15-27.

Wirawan. (2013). Konflik dan Manajemen Konflik: Teori, Aplikasi dan Penelitian. Jakarta: Salemba Humanika. 